\title{
Bioactive Properties, Fatty Acid Composition and Mineral Contents of Grape Seed and Oils
}

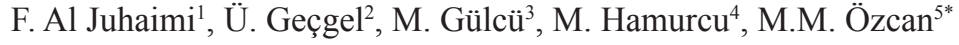 \\ (1) Department of Food Science \& Nutrition, College of Food and Agricultural Sciences, King Saud University, Riyadh-Saudi \\ Arabia \\ (2) Department of Food Engineering, Faculty of Agriculture, Namık Kemal University, Tekirdağ, Turkey \\ (3) Ministry of Food, Agriculture and Livestock Viticultural Research Station, 59100, Süleymanpaşa, Tekirdağ, Turkey \\ (4) Department of Soil Science and Plant Nutrition, Faculty of Agriculture, Selcuk University 42079 Campus, Konya Turkey \\ (5) Department of Food Engineering, Faculty of Agriculture, Selcuk University, 42079 Konya, Turkey
}

Submitted for publication: October 2016

Accepted for publication: November 2016

Key words: Grape seed, varieties, oil, fatty acid, phenol, flavonoid, minerals

\begin{abstract}
The oil content of grape seed samples changed between 4.53\% (Adakarası) and 11.13\% (Sauvignon blanc). While the linoleic acid contents of grape seed oils ranged from $\mathbf{4 7 . 3 4 \%}$ (Sangiovese) to $\mathbf{7 2 . 9 1 \%}$ (Cinsaut), the oleic acid contents varied between 13.35\% (Cabernet Sauvignon) and 26.30\% (Sangiovese) $(p<0.05)$. Also, the palmitic acid and stearic acid contents of grape seed oils ranged from 7.15\% (Cinsaut) to $\mathbf{1 6 . 0 6 \%}$ (Sangiovese) and from $\mathbf{2 . 4 3 \%}$ (Narince) to $6.55 \%$ (Sangiovese) respectively $(\mathrm{p}<\mathbf{0 . 0 5}$ ). The flavonoid contents of the seeds changed between 263.53 (mg CE/g) and 1706.00 (mg CE/g) (Cabernet Sauvignon). Total phenols were found to be between 6711.14 (mg GA/g extract) (Sangiovese) and 8818.69 (mg GA/g extract) (Narince). The linoleic contents of oils changed from between $47.34 \%$ (Sangiovese) and $72.91 \%$ (Cinsaut). The $\mathrm{K}$ contents of the grape seed samples changed between $4347.80 \mathrm{mg} / \mathrm{kg}$ (Cabernet Sauvignon) and $9492.60 \mathrm{mg} / \mathrm{kg}$ (Gamay) $(\mathrm{p}<0.05)$. The Fe contents of seeds were found to be between $29.96 \mathrm{mg} / \mathrm{kg}$ (Narince) and $73.82 \mathrm{mg} / \mathrm{kg}$ (Sangiovese). As a result, the current study shows that grape seeds are useful for human nutrition due to their components.
\end{abstract}

\section{INTRODUCTION}

Grapevines (Vitis vinifera L.) are grown in the temperate and tropical regions of the world for fresh fruit, raisins, juice and wine (Winkler et al., 1974; Riaz et al., 2004). People in Italy, France, Spain, Turkey and Greece have benefited from the by-products of wine, vinegar, grape juice and "pekmez" (boiled grape juice). Most of the seeds (about 20\% to 26\% of the pomace) are produced in large quantities by wineries (Kamel et al., 1985; Göktürk Baydar \& Akkurt, 2001). Grape species have economic importance in both the fresh and processed fruit markets. Generally, a large amount of grape seeds are obtained from the waste of processed fruit products, like juice, jam or marmalade and boiled juice. The wastes of this industry, such as peels, seeds and pulps, represent about $50 \%$ to $60 \%$ of the raw processed fruit. Besides being a potentially valuable waste resource, they also aggravate already serious disposal problems. In recent years, grape seed has attracted attention due to the further use of the grape seeds as a potential source of other nutrients. Obviously, such utilisation would improve the utilisation of the available resources and result in the production of various products for food. On the other hand, grape seeds are used as a source of oil, as they have nutritional and bioactive constituents (Kamel et al., 1985; Göktürk Baydar \& Akkurt, 2001; Hassanein \& Abedel-Razek, 2009). Also, grape seeds have a high protein content (Hassanein \& Abedel-Razek, 2009). They also contain $10 \%$ to $20 \%$ oil (Schester et al., 1992; Laufenberg et al., 2003; Akın \& Altındişli, 2011) with a high vitamin $\mathrm{E}$ content, which is important for human health (Barron et al., 1988). Ashraf and Taylor (2004) researched the polyphenol and procyanidin compounds from grape seeds. Nakamura et al. (2003) studied the procyanidins of grape seed extracts, and health foods containing grape seed extract and oils. It was established that grape seed oil is rich in unsaturated fatty acids, such as linoleic acid (72\% to 76\%) (Citil et al., 2010; Akın \& Altındişli, 2011). Generally, grape seed oil is used for salad dressings, marinades, deep frying, flavoured oils, baking, massage oil, sunburn repair lotion, hair products and hand creams (Akın \& Altındişli, 2011). Due to the importance of grape seeds as sources of oil, minerals and proteins, the aim of this study was to determine some chemical properties, fatty acids and minerals of grape seeds in eleven grape cultivars.

*Corresponding author: E-mail address: mozcan@selcuk.edu.tr

Acknowledgements: The authors extend their appreciation to the International Scientific Partnership Programme (ISPP) at King Saud University for funding this research work through ISPP\# 0015 


\section{MATERIALS AND METHODS \\ Materials}

The grape fruits were obtained from the Tekirdağ Vineyard Research Centre in Turkey (Table 1). The grapes were crushed in the winery to remove the stems. The seeds were separated from the crushed grapes and washed with distilled water. The seeds were dried for in an oven for $24 \mathrm{~h}$ at $70^{\circ} \mathrm{C}$.

\section{Oil extraction}

Oil was extracted from ground seeds with petroleum ether in a Soxhlet extractor for $6 \mathrm{~h}$. The solvent (petroleum ether) was then evaporated. The obtained oil was kept in coloured bottles at $-18^{\circ} \mathrm{C}$ before analysing.

\section{Fatty acid composition}

The oil samples (50 mg to $100 \mathrm{mg}$ ) were converted to their fatty acid methyl esters (FAME). The fatty acid methyl esters were identified by comparing the retention time of the samples with the appropriate fatty acid methyl ester standards (Hış1l, 1998). The fatty acid methyl ester was injected into a Varian 5890 gas chromotograph with a capillary column, CP-Sil 88 (100 m long, $0.25 \mathrm{~mm}$ ID, film thickness $0.2 \mu \mathrm{m}$ ).

\section{Determination of mineral and protein contents}

Grape seed samples were dried in a drying cabinet at $70^{\circ} \mathrm{C}$. About $0.5 \mathrm{~g}$ of sample was digested in a closed microwave system by using $5 \mathrm{ml}$ of $65 \% \mathrm{HNO}_{3}$ and $2 \mathrm{ml}$ of $35 \%$ $\mathrm{H}_{2} \mathrm{O}_{2}$. Then $20 \mathrm{ml}$ of ultra-deionised water was added to the digested sample, and the sample was examined by ICP AES (Varian-Vista, Australia) for minerals (Skujins, 1998). The protein determination was done in a Leco combustion analyser and 6.25 was used as the conversion factor. The crude protein content of the samples was determined according to the Association of Official Analytical Chemists (AACC International, 1999).

\section{Determination of anthocyanins and total phenolic and flavonoid contents}

The anthocyanin contents of the plant samples were analysed according to the method of Ticconi et al. (2001). After $0.5 \mathrm{~g}$ fresh weight $(\mathrm{FW})$ was homogenised in a solution containing propanol, hydrochloric acid and water $(18: 1: 81)$, the homogenate was boiled in a water bath for $3 \mathrm{~min}$ and then left in darkness for $24 \mathrm{~h}$ at room temperature. A total of $3 \mathrm{~mL}$ of the supernatant was centrifuged at $6500 \mathrm{rpm}$ for $40 \mathrm{~min}$. Finally, the absorbencies of the samples were measured at 535 and $650 \mathrm{~nm}$.

The phenols of the plants were determined according to Madaan et al. (2011). Absorbances were measured at $765 \mathrm{~nm}$ using a UV/VIS spectrophotometer (Schimadzu, Japan) against a blank.

The total flavonoid contents (mg CE/g) of the seeds were estimated according to Dewanto et al. (2002). Methanol extracts were properly diluted with distilled water. Then $5 \% \mathrm{NaNO}_{2}$ solution was added to each test tube, and it was allowed to stand for five minutes. Then percent $\mathrm{AlCl}_{3}$ solution then was added and, after six minutes, 1.0 M NaOH was added. The total volume was filled to $5 \mathrm{~mL}$ with water, and the test tubes were mixed. Solution absorbance was measured at $510 \mathrm{~nm}$ versus a blank. The calibration curve was prepared using catechol as standard.

\section{Statistical analyses}

Analysis of variance (ANOVA) was calculated by using JMP version 9.0 (SAS Inst. Inc., Cary, N.C., U.S.A.) and the mean \pm standard deviation (MSTAT C) of the results was calculated according to Püskülcü and İkiz (1989).

\section{RESULTS AND DISCUSSION}

The oil, protein, flavonoid, total phenol and total anthocyanin contents of the grape seeds are given in Table 2. The oil contents of the seeds ranged from $4.53 \%$ (Ada Karas1) to $11.13 \%$ (Sauvignon blanc) $(\mathrm{p}<0.05)$. In a previous study, the oil contents of some Turkish grape seeds were found to be between $8.09 \%$ (Dökülgen) and $13.24 \%$ (Hesap Ali) (Akın \& Altındişli, 2011). Hassanein and Abadel-Razek (2009) determined $12.0 \%$ oil in grape seed. In another study, the oil contents of grape seeds ranged between $11.6 \%$ and 19.6\% (Göktürk Baydar \& Akkurt, 2001; Göktürk Baydar et al., 2007). The protein contents of the grape seed samples varied between $7.51 \%$ (Chardonnay) and 13.28\% (Sauvignon blanc). Fazlo et al. (1982) reported that grape seed contained $13.64 \%$ crude protein. In addition, Kamel et al. (1985) determined $8.4 \%$ protein in grape seed. While

TABLE 1

Grape seeds used in experiment.

\begin{tabular}{llll}
\hline Grape varieties & Parts used & Seed amount (g) & Origin \\
\hline Alphonse Lavallé & Seed & 250 & France \\
Ada Karası & Seed & 250 & Turkey \\
Sauvignon blanc & Seed & 250 & France \\
Sangiovese & Seed & 250 & Italy \\
Papaz Karası & Seed & 250 & Turkey \\
Narince & Seed & 250 & Turkey \\
Gamay & Seed & 250 & France \\
Semillon & Seed & 250 & France \\
Cinsaut & Seed & 250 & France \\
Chardonnay & Seed & 250 & France \\
Cabernet Sauvignon & Seed & 250 & France
\end{tabular}


TABLE 2

Chemical properties of grape seeds $(\mathrm{dw})$.

\begin{tabular}{llllll}
\hline Grape varieties & $\begin{array}{l}\text { Crude oil } \\
\mathbf{( \% )}\end{array}$ & $\begin{array}{l}\text { Crude protein } \\
\mathbf{( \% )}\end{array}$ & $\begin{array}{l}\text { Flavonoid } \\
(\mathbf{m g} \text { CE/g) }\end{array}$ & $\begin{array}{l}\text { Total phenolics } \\
(\mathbf{m g} \text { GA/g extract) }\end{array}$ & $\begin{array}{l}\text { Anthocyanins } \\
(\boldsymbol{\mu m o l} / \mathbf{g ~ d w})\end{array}$ \\
\hline Alfons Lavallé & $8.60 \pm 1.08 * \mathrm{~b}$ & $11.54 \pm 0.25 \mathrm{~b}$ & $519.50 \pm 3.05 \mathrm{c}$ & $8718.47 \pm 3.41 \mathrm{a}$ & $0.80 \pm 0.04 \mathrm{~b}$ \\
Ada Karası & $4.53 \pm 0.98 \mathrm{~d}^{* *}$ & $12.89 \pm 0.53 \mathrm{a}$ & $448.57 \pm 4.97 \mathrm{c}$ & $8644.28 \pm 3.93 \mathrm{a}$ & $0.55 \pm 0.03 \mathrm{c}$ \\
Sauvignon blanc & $11.13 \pm 1.27 \mathrm{a}$ & $13.28 \pm 0.12 \mathrm{a}$ & $263.53 \pm 3.61 \mathrm{~d}$ & $6791.43 \pm 4.21 \mathrm{c}$ & $0.47 \pm 0.02 \mathrm{c}$ \\
Sangiovese & $10.66 \pm 1.17 \mathrm{a}$ & $11.89 \pm 0.24 \mathrm{~b}$ & $967.90 \pm 3.25 \mathrm{~b}$ & $6711.14 \pm 5.72 \mathrm{c}$ & $0.31 \pm 0.03 \mathrm{c}$ \\
Papaz Karası & $6.26 \pm 0.78 \mathrm{c}$ & $7.85 \pm 0.18 \mathrm{c}$ & $348.30 \pm 1.55 \mathrm{~d}$ & $7556.38 \pm 4.33 \mathrm{~b}$ & $0.66 \pm 0.03 \mathrm{~b}$ \\
Narince & $9.40 \pm 0.83 \mathrm{a}$ & $7.70 \pm 0.10 \mathrm{c}$ & $647.00 \pm 5.57 \mathrm{c}$ & $8818.69 \pm 2.56 \mathrm{a}$ & $0.86 \pm 0.06 \mathrm{~b}$ \\
Gamay & $7.26 \pm 0.91 \mathrm{~b}$ & $7.83 \pm 0.13 \mathrm{c}$ & $426.73 \pm 170.39 \mathrm{c}$ & $8793.72 \pm 2.85 \mathrm{a}$ & $0.56 \pm 0.05 \mathrm{c}$ \\
Semillon & $7.20 \pm 0.89 \mathrm{~b}$ & $7.99 \pm 0.40 \mathrm{c}$ & $436.47 \pm 3.70 \mathrm{c}$ & $8346.81 \pm 3.75 \mathrm{a}$ & $0.34 \pm 0.04 \mathrm{c}$ \\
Cinsaut & $5.93 \pm 0.67$ & $7.74 \pm 0.03$ & $378.10 \pm 3.16 \mathrm{~d}$ & $8593.11 \pm 3.41 \mathrm{a}$ & $2.55 \pm 0.06 \mathrm{a}$ \\
Chardonnay & $9.26 \pm 0.09 \mathrm{a}$ & $7.51 \pm 0.07 \mathrm{c}$ & $533.50 \pm 3.25 \mathrm{c}$ & $8765.50 \pm 3.85 \mathrm{a}$ & $0.49 \pm 0.02 \mathrm{c}$ \\
Cabernet Sauvignon & $10.06 \pm 0.87 \mathrm{a}$ & $7.79 \pm 0.07 \mathrm{c}$ & $1706.00 \pm 5.00 \mathrm{a}$ & $8229.01 \pm 3.18 \mathrm{a}$ & $0.76 \pm 0.04 \mathrm{~b}$ \\
\hline
\end{tabular}

$*$ mean \pm standard deviation; ** means in the same row with the same letters are not significantly different $(\mathrm{p}<0.05)$

the flavonoid contents of grape seeds varied between 263.53 (Sauvignon blanc) and $1706.00 \mathrm{mg} \mathrm{CE} / \mathrm{g}$ (Cabernet Sauvignon), the total phenol contents of grape seeds ranged from 6711.14 (Sangiovese) to $8818.69 \mathrm{mg} \mathrm{GA} / \mathrm{g}$ extract (Narince). Also, the anthocyanin contents of seeds varied between 0.31 (Sangiovese) and $2.55 \mu \mathrm{mol} / \mathrm{g}$ dry weight (dw) (Cinsaut). The crude oil and protein contents of grape seeds were found to differ somewhat from the results in the literature. These differences can be due to grape cultivars, agronomic conditions and the ripening period of the grapes.

The fatty acid composition of grape seed oils is shown in Table 3. The results reveal that grape seed oils are rich in linoleic oleic and palmitic and stearic acids. While the linoleic acid contents of grape seed oils range from $47.34 \%$ (Sangiovese) to $72.91 \%$ (Cinsaut), the oleic acid contents of seed oils vary between $13.35 \%$ (Cabernet Sauvignon) and $26.30 \%$ (Sangiovese) $(\mathrm{p}<0.05)$. Also, the palmitic acid and stearic acid contents of grape seed oils range from $7.15 \%$ (Cinsaut) to $16.06 \%$ (Sangiovese), and from $2.43 \%$ (Narince) to $6.55 \%$ (Sangiovese) respectively ( $<<0.05$ ). The linoleic acid was the key fatty acid in grape seed oil, followed by palmitic and oleic acids. Other fatty acids were found in small quantities. Five grape cultivar seed oils contained $6.7 \%$ to $8.9 \%$ palmitic acid, $1.1 \%$ to $5.3 \%$ stearic acid, $9.7 \%$ to $17.5 \%$ oleic acid, $69.2 \%$ to $80.5 \%$ linoleic acid, and $<0.1 \%$ palmitoleic and linolenic acids (Ohnishi et al., 1990). In other study, grape seed oil was found to contain $6.7 \%$ to $9.1 \%$ palmitic acid, $13.4 \%$ to $20.7 \%$ oleic acid, and $68.1 \%$ to $78.1 \%$ linoleic acid (Yoo et al., 1984). In the seed oils of red and white Italian grapes, Riccardo and Muratore (1993) determined 65.9\% and 62.2\% linoleic, $18.6 \%$ and $16.9 \%$ oleic, $11.6 \%$ and $10.7 \%$ palmitic, $3.8 \%$ and $3.4 \%$ stearic, and $3.5 \%$ and $2.8 \%$ myristic acid respectively. Won Young et al. (2000) reported that linoleic, oleic, palmitic and stearic acids were the main fatty acids of grape seed oil. The oils of grape seed cultivars contained $8.40 \%$ to $6.51 \%$ palmitic acid, $16.1 \%$ to $11.62 \%$ oleic acid, $77.59 \%$ to
$72.50 \%$ linoleic acid and $3.86 \%$ to $3.07 \%$ stearic acid (Uslu \& Dardeniz, 2009). Grape seed oil contained $4.1 \%$ palmitic, $10.4 \%$ stearic, $16.4 \%$ oleic and $69.3 \%$ linoleic acid (Özcan et al., 2010). The results as they related to the grape seed oils were very similar to the findings in the literature. As a result, it can be stated that there is a slight variation among cultivars in fatty acid composition. It therefore is concluded that the seeds as a by-product of the grape-processing industries could be benefited for mainly edible oil and other functional components.

Table 4 shows the mineral contents of 11 grape seeds. The P contents of the seed samples varied between 2277.65 (Papaz karas1) and $3232.42 \mathrm{mg} / \mathrm{kg}$ (Chardonnay). In addition, while the $\mathrm{K}$ contents of grape seeds varied from 4347.80 (Cabernet Sauvignon) to $9492.60 \mathrm{mg} / \mathrm{kg}$ (Gamay), the $\mathrm{Ca}$ contents of seeds ranged from 5115.58 (Chardonnay) to $8036.76 \mathrm{mg} / \mathrm{kg}$ (Ada Karas 1$)(\mathrm{p}<0.05)$. Also, the $\mathrm{Mg}$ contents of the samples were found to be between 1249.18 (Ada Karas1) and $2073.90 \mathrm{mg} / \mathrm{kg}$ (Alfons Lavallé). In addition, the $\mathrm{Fe}$ contents of the grape seeds ranged from 29.96 (Narince) to $73.82 \mathrm{mg} / \mathrm{kg}$ (Sangiovese). While the $\mathrm{Zn}$ contents of the seeds varied from 8.27 (Narince) to $15.93 \mathrm{mg} / \mathrm{kg}$ (Semillon), the Mn contents of the grape seeds ranged from 2.08 (Ada Karası) to $11.59 \mathrm{mg} / \mathrm{kg}$ (Cinsaut). The $\mathrm{Cu}$ contents of the seeds ranged between 8.62 (Narince) and $15.28 \mathrm{mg} / \mathrm{kg}$ (Chardonnay). According to Fazlo et al. (1982), the mean values of the $\mathrm{Na}, \mathrm{K}$ and $\mathrm{Ca}$ contents of grape seeds were 4660,124000 and $271000 \mathrm{mg} / \mathrm{kg}$ respectively. Grape seeds can be used as a source of edible vegetable oil. It is concluded that the seeds as a by-product of the grape-processing industries in Turkey could be benefited for mainly edible oil and the other functional components. Some differences were observed in the concentrations of minerals when compared with the values in the literature. The differences in results could probably be due to differences in genetic factor, variety and cultural factors during the maturation of grape seeds. 


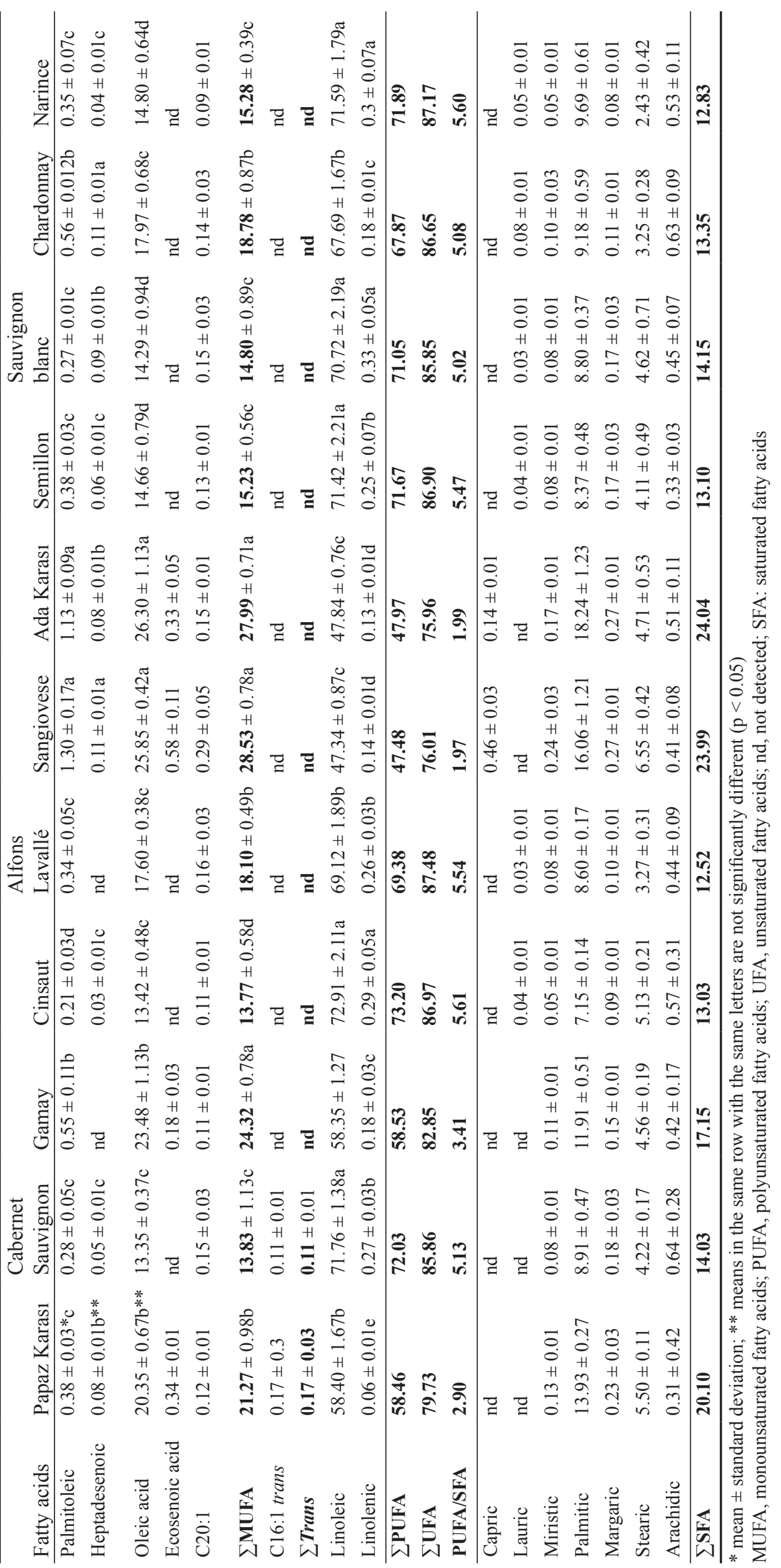


TABLE 4

Mineral contents of grape seeds $(\mathrm{mg} / \mathrm{kg})$

\begin{tabular}{llllll}
\hline \multicolumn{5}{c}{ Macro and Micro Elements } \\
\hline Variety & $\mathbf{P}$ & $\mathbf{K}$ & $\mathbf{C a}$ & $\mathbf{M g}$ & $\mathbf{S}$ \\
\hline Alfons Lavallé & $2819.70 \pm 139.95^{*} \mathrm{a}$ & $5514.82 \pm 248.27 \mathrm{~b}$ & $6469.68 \pm 145.97 \mathrm{~b}$ & $2073.90 \pm 98.24 \mathrm{a}$ & $1259.28 \pm 65.19 \mathrm{c}$ \\
Ada Karası & $2369.81 \pm 175.16 \mathrm{~d}^{* *}$ & $3118.23 \pm 158.42 \mathrm{c}$ & $8036.76 \pm 251.04 \mathrm{a}$ & $1249.18 \pm 71.45 \mathrm{~b}$ & $1034.62 \pm 2.76 \mathrm{~d}$ \\
Sauvignon blanc & $2467.59 \pm 126.53 \mathrm{c}$ & $4691.39 \pm 286.21 \mathrm{c}$ & $5703.37 \pm 167.53 \mathrm{c}$ & $1450.11 \pm 71.24 \mathrm{~b}$ & $1161.09 \pm 60.28 \mathrm{c}$ \\
Sangiovese & $2624.86 \pm 226.28 \mathrm{~b}$ & $4535.41 \pm 482.03 \mathrm{c}$ & $6961.80 \pm 551.52 \mathrm{~b}$ & $1446.84 \pm 120.17 \mathrm{~b}$ & $1284.27 \pm 113.86 \mathrm{c}$ \\
Papaz Karası & $2277.65 \pm 50.71 \mathrm{~d}$ & $4225.64 \pm 81.97 \mathrm{c}$ & $5411.08 \pm 222.39 \mathrm{c}$ & $1397.00 \pm 34.75 \mathrm{~b}$ & $1164.64 \pm 30.82 \mathrm{c}$ \\
Narince & $3209.13 \pm 338.00 \mathrm{a}$ & $7798.37 \pm 524.62 \mathrm{~b}$ & $6282.62 \pm 438.61 \mathrm{~b}$ & $1421.41 \pm 175.71 \mathrm{~b}$ & $1163.19 \pm 105.95 \mathrm{c}$ \\
Gamay & $2754.93 \pm 232.41 \mathrm{~b}$ & $9492.60 \pm 552.01 \mathrm{a}$ & $6132.39 \pm 637.18 \mathrm{~b}$ & $1390.66 \pm 141.03 \mathrm{~b}$ & $1232.66 \pm 83.24 \mathrm{c}$ \\
Semillon & $2766.89 \pm 45.63 \mathrm{~b}$ & $2792.62 \pm 170.33 \mathrm{~d}$ & $6560.52 \pm 119.61 \mathrm{~b}$ & $1315.17 \pm 40.56 \mathrm{~b}$ & $5232.18 \pm 126.73 \mathrm{a}$ \\
Cinsaut & $2444.18 \pm 357.81 \mathrm{c}$ & $4680.35 \pm 469.38 \mathrm{c}$ & $5807.15 \pm 372.94 \mathrm{c}$ & $1469.66 \pm 271.39 \mathrm{~b}$ & $1125.37 \pm 134.30 \mathrm{c}$ \\
Chardonnay & $3232.42 \pm 348.94 \mathrm{a}$ & $6911.97 \pm 763.60 \mathrm{~b}$ & $5115.58 \pm 538.96 \mathrm{c}$ & $1721.41 \pm 175.67 \mathrm{a}$ & $1526.00 \pm 160.54 \mathrm{~b}$ \\
Cabernet Sauvignon & $2823.77 \pm 143.67 \mathrm{~b}$ & $4347.80 \pm 231.58 \mathrm{c}$ & $5363.30 \pm 118.02 \mathrm{c}$ & $1451.34 \pm 63.29 \mathrm{~b}$ & $1363.97 \pm 68.44 \mathrm{c}$ \\
\hline
\end{tabular}

$*$ mean \pm standard deviation; $* *$ means in the same row with the same letters are not significantly different $(\mathrm{p}<0.05)$

TABLE 4 (CONTINUED)

\begin{tabular}{llllll}
\hline \multicolumn{7}{c}{ Macro and Micro Elements } \\
\hline Variety & $\mathbf{F e}$ & $\mathbf{Z n}$ & $\mathbf{M n}$ & $\mathbf{B}$ & $\mathbf{C u}$ \\
\hline Alfons Lavallé & $48.87 \pm 2.17 \mathrm{c}$ & $8.40 \pm 1.25 \mathrm{c}$ & $8.88 \pm 2.22 \mathrm{~b}$ & $20.89 \pm 1.80 \mathrm{a}$ & $12.32 \pm 0.48 \mathrm{~b}$ \\
Ada Karası & $42.79 \pm 4.46 \mathrm{~d}$ & $11.71 \pm 0.95 \mathrm{~b}$ & $2.08 \pm 0.75 \mathrm{~d}$ & $14.30 \pm 0.82 \mathrm{~b}$ & $10.88 \pm 0.59 \mathrm{c}$ \\
Sauvignon blanc & $49.26 \pm 2.54 \mathrm{c}$ & $10.41 \pm 4.66 \mathrm{~b}$ & $4.11 \pm 0.39 \mathrm{c}$ & $15.57 \pm 0.96 \mathrm{~b}$ & $10.93 \pm 0.40 \mathrm{c}$ \\
Sangiovese & $73.82 \pm 26.35 \mathrm{a}$ & $10.89 \pm 1.61 \mathrm{~b}$ & $8.96 \pm 1.32 \mathrm{~b}$ & $19.34 \pm 1.33 \mathrm{a}$ & $13.35 \pm 0.73 \mathrm{~b}$ \\
Papaz Karası & $69.90 \pm 22.12 \mathrm{a}$ & $8.79 \pm 0.14 \mathrm{c}$ & $9.36 \pm 1.14 \mathrm{a}$ & $16.39 \pm 1.87$ & $13.89 \pm 0.87 \mathrm{~b}$ \\
Narince & $29.96 \pm 6.19 \mathrm{~d}$ & $8.27 \pm 1.95 \mathrm{c}$ & $10.50 \pm 2.55 \mathrm{a}$ & $18.03 \pm 2.21 \mathrm{a}$ & $8.62 \pm 0.68$ \\
Gamay & $50.65 \pm 3.67 \mathrm{c}$ & $11.28 \pm 1.62 \mathrm{~b}$ & $9.29 \pm 1.70 \mathrm{a}$ & $18.53 \pm 1.62 \mathrm{a}$ & $15.15 \pm 0.63 \mathrm{a}$ \\
Semillon & $51.18 \pm 3.87 \mathrm{c}$ & $15.93 \pm 0.71 \mathrm{a}$ & $10.89 \pm 0.20 \mathrm{a}$ & $13.00 \pm 0.91 \mathrm{~b}$ & $11.60 \pm 0.28 \mathrm{c}$ \\
Cinsaut & $51.53 \pm 5.06 \mathrm{c}$ & $10.84 \pm 1.54 \mathrm{~b}$ & $11.59 \pm 1.71$ & $9.39 \pm 1.85 \mathrm{c}$ & $10.07 \pm 0.96 \mathrm{c}$ \\
Chardonnay & $56.91 \pm 8.31 \mathrm{~b}$ & $11.21 \pm 2.41 \mathrm{~b}$ & $8.96 \pm 1.32 \mathrm{~b}$ & $14.75 \pm 1.80 \mathrm{~b}$ & $15.28 \pm 1.45 \mathrm{a}$ \\
Cabernet Sauvignon & $64.75 \pm 3.04 \mathrm{a}$ & $14.02 \pm 4.40 \mathrm{a}$ & $7.76 \pm 0.96 \mathrm{~b}$ & $12.86 \pm 1.30 \mathrm{c}$ & $12.90 \pm 1.23 \mathrm{~b}$ \\
\hline
\end{tabular}

$*$ mean \pm standard deviation; $* *$ means in the same row with the same letters are not significantly different $(\mathrm{p}<0.05)$

\section{LITERATURE CITED}

AACC International (1999) Approved Methods of Analysis, 11th Ed Method 26-21.02. Experimental Milling-Bühler Method for Hard Wheat. Approved November 3, 1999. AACC International, St. Paul, MN, USA http://dx.doi.org/10.1094/AACCIntMethod-26-21-02.

Akın, A. \& Altındişli, A., 2011. Determination of fatty acid composition and lipid content of some grape cultivar seeds in Turkey. Biyol. Sci. Res. J. 4, 13-15.

Ashraf, K.M. \& Taylor, L.T., 2004. Sequential fractionation of grape seeds into oils, polyphenols, and procyanidins via a single system employing $\mathrm{CO}_{2}$ based fluids. J. Agric. Food Chem. 52, 2440-2444.

Barron, L.J.R., Celaa, M.V., Santa-Maria, G. \& Corzo, N., 1988. Determination of the triglyceride composition of grapes by HPLC Chromatogr. 25(7), 609-612.

Citil, O.B., Sezgin, M., Guler, G.O. \& Aktümsek, A., 2010. Fatty acid compositions of some feed raw materials in poultry diets. Asian J. Chem. 22, 3785-3792.
Dewanto, V., Wu, X., Adom, K.K. \& Liu, R.H., 2002. Thermal processing enhances the nutritional value of tomatoes by increasing total antioxidant activity. J. Agric. Food Chem. 50(10), 3010-3014.

Fazlo, G., Gilluffo, V., Indovina, M.C. \& Pirrone, L., 1982. Grape seed. I. Characteristics and composition of the meal. Riv. Soc. Ital. Sci. Aliment. $11,349-354$.

Göktürk Baydar, N. \& Akkurt, M., 2001. Oil content and oil quality properties of some grape seeds. Turk J. Agric. Forestr. 25, 161-168.

Göktürk Baydar, N., Özkan, G., Çetin, E.S. 2007. Characterization of grape seed and pomace oil extracts. Grasas y Aceites 58, 29-33.

Hassanein, M.M.M. \& Abedel-Razek, A.G., 2009. Chromatographic quantitation of some bioactive minor components in oils of wheat germ and grape seeds produced as by-products. J. Oleo Sci. 58, 227-233.

Hișil, Y., 1998. Instrumental analysis techniques (Eng. Fac. Publ. 55). Ege University, Bornova -İzmir (in Turkish).

Kamel, B.S., Dawson, H. \& Kakuda, Y., 1985. Characteristics and composition of melon and grape seed oils and cakes. J. Am. Oil Chem. Soc. $62,881-883$ 
Laufenberg, G., Kunz, B. \& Nystroem, N., 2003. Transformation of vegetable waste into value added products, (A) the upgrading concept, (B) practical implementations. Biores. Technol. 87, 167-198.

Madaan, R., Bansal, G., Kumar, S. \& Sharma, A., 2011. Estimation of total phenols and flavonoids in extracts of Actaeaspicata roots and antioxidant activity studies. Indian J. Pharm. Sci. 73(6), 666-669.

Nakamura, Y., Tsuji, S. \& Tonogai, Y., 2003. Analysis of proanthocyanidins in grape seed extracts, health foods and grape seed oils. J. Health Sci. 49, 45-54.

Ohnishi, M., Hirose, S., Kawaguchi, M., Ho, S. \& Fujino, Y., 1990. Chemical composition of lipids, especially triaglycerol, in grape seeds. Agric. Biol. Chem. 54(4), 1035-1042.

Özcan, M.M., Endes, Z. \& Er, F., 2010. Physical and chemical properties of some seed and kernel oils. Asian J. Chem. 22(8), 6531-6536.

Püskülcü, H. \& İkiz, F., 1989. Introduction to statistics. Bilgehan Press, Bornova, İzmir, Turkey (in Turkish).

Riaz, S., Dangl, G.S., Edwards, K.J. \& Meredith, C.J., 2004. A microsatellite marker based framework linkage map of Vitis vinifera L. Theoretical Appl. Gen. 108, 864-872.
Schester, W.H., 1992. Ölflanzen im Europa. DLG-Verlag, Frankfurt am Main.

Skujins, S., 1998. Handbook for ICP-AES (Varıan-Vista). A short guide to Vista Series ICP-AES operation. Varian Int. AGşZug. Version 1.0. Switzerland.

Ticconi, C.A., Delatorre C.A. \& Abel, S., 2001. Attenuation of phosphate starvation responses by phosphite in Arabidopsis. Plant Physiol. 127(3), 963-972.

Uslu, A. \& Dardeniz, A., 2009. Determination of fatty acid compositions in the seeds of some grape cultivars. Selçuk Tar. Gıda Bil. Derg. 23, 13-19.

Weiss, E.A., 1983. Sesame. In: Oilseed crops. Longman Inc., New York, pp 282-340.

Winkler, A., Cook, J., Klieweri, W. \& Lider, L., 1974. General viticulture. Berkeley: University of California Press.

Won Young, L., Young, J.C., Sang, L.O., Joon, H.P., Woen, S.C., Jae, Y.J. $\&$ Yong, H.C., 2000. Extraction of grape seed oil by supercritical $\mathrm{CO}_{2}$ and ethanol modifier. Food Sci. Biotechnol. 9, 174-178

Yoo, J.Y., Shin, D.H. \& Min, B.Y., 1984. Composition of grape seed oil. Korean J. Food Sci. Technol. 16, 257-260. 